\title{
Immunochemical Estimation of Some Proteins in Nigerian Paired Maternal and Fetal Blood ${ }^{\star}$
}

\author{
H. MCFARLANE and I. O. K. UDEOZO \\ From the Department of Chemical Pathology, University of Ibadan, Ibadan, Nigeria
}

The immune response in an individual is relevant to his survival, and this is especially true of people living in Africa where they are constantly challenged by a host of parasitic antigens. The antibodies which result from such immune response are found in the immunoglobulins: IgA, IgG, IgM, and IgD. Thus the concentration of these immune substances in the circulation provides some useful index of the immune state of the individual.

Within the past 2 years immunochemical estimation of immunoglobulins at this institution and at a few other centres in parts of Africa has been concerned with immunoglobulin in the African adult (Lamy, 1965; McFarlane, 1966; Turner and Voller, 1966; McFarlane and Voller, 1966; D. Rowe, 1966, immunoglobulins in Gambians, personal communication; Charmot and Andre, 1966; J. E. Tobie, 1966, immunoglobulins in Ghanaians, personal communication). Michaux, Heremans, and Hitzig (1966) compared the level of IgG in cord blood serum in the Central African Bantu and the Swiss Caucasian. As far as is known there are no reports concerning the immunochemical quantitations of transferrin and caeruloplasmin in the African, though Edozien and Udeozo (1960) have reported values for serum iron and iron-binding capacity and serum copper in kwashiorkor, and Edozien (1961), using paper electrophoresis, studied the level of $\gamma$-globulin in both Nigerian and Caucasian maternal and fetal blood.

With the development of more accurate and specific methods for quantitating the various immunoglobulins, it seemed of interest to investigate the various immunoglobulins and caeruloplasmin and transferrin in paired maternal-fetal blood, in order to obtain more information concerning the physiological development of these proteins, and their transfer across the human placenta.

\footnotetext{
Received April 3, 1967.

* A part of this work was read at the VI International Congress of Clinical Chemistry, in Munich, July 1966.
}

\section{Materials and Methods}

Forty-five healthy umbilical cord and maternal blood specimens were obtained immediately after parturition. 24 of these specimens, which were paired maternalfetal blood, were obtained in April and May. 21 were fetal blood only and were obtained in September and October. The group included one pair of monozygotic and one pair of dizygotic twins and one set of trizygotic triplets. Sera were stored at $-20^{\circ} \mathrm{C}$. for not more than three weeks before the various quantitative assays were performed.

Immunochemical estimations were carried out using the Hyland Laboratories immunoplate method. Briefly, the method consisted of measuring the diameter of the ring of antibody-antigen precipitate formed after the antigen was added to the well in the antibody incorporated agar plate. The diameter for each ring was then read off a calibration curve which was plotted for each run and for each protein measured. At least three different Hyland standards of known protein concentration were used for each calibration curve. The IgG and transferrin plates were read after incubation for 4 hours at $37^{\circ} \mathrm{C}$., whereas the IgA and IgM and caeruloplasmin plates were read after incubation for 16 hours at $18^{\circ} \mathrm{C}$. in an air-conditioned laboratory.

\section{Results}

The coefficient of variation of 10 separate estimations of a single specimen of serum for each protein measured was: IgG 9\%, IgM 14\%, IgA $15 \%$, caeruloplasmin $7 \%$, and transferrin $5 \%$.

In carrying out these observations on different occasions on the same specimen or on a single set of known standards, it was observed that closer agreement was obtained for IgG, transferrin, and caeruloplasmin than for the IgA and IgM. This may be due to the heterogeneity of the size of the IgA and IgM molecules (Fahey and McKelvey, 1965). The IgA proteins occur as $7 \mathrm{~S}, 9 \mathrm{~S}, 11 \mathrm{~S}$, and $13 \mathrm{~S}$; the IgM as $19 \mathrm{~S}, 24 \mathrm{~S}$, and $32 \mathrm{~S}$. The other proteins IgG, transferrin, and caeruloplasmin are known to have consistent sedimentation values.

The results are summarized in Table $I$, where it 
TABLE I

Immunoglobulins, Caeruloplasmin, and Transferrin in Maternal and Cord Blood (mg./ml.)

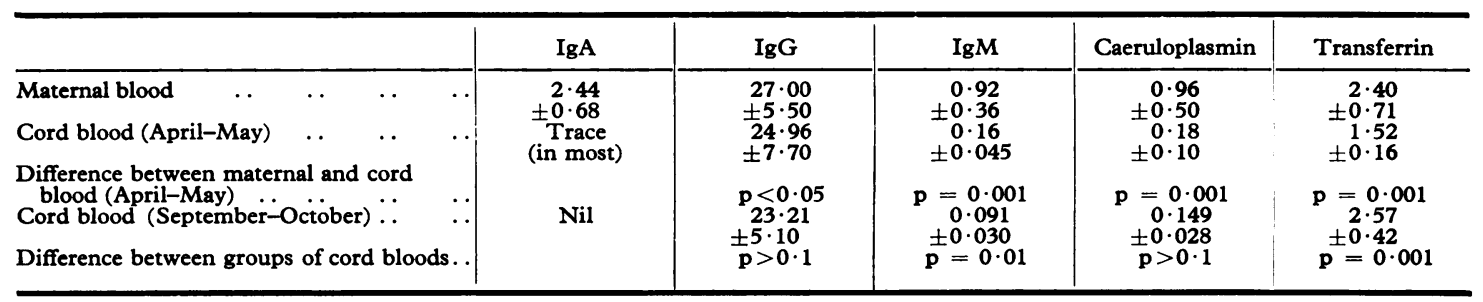

is shown that the mean value for $\operatorname{IgA}$ in maternal blood was $2.44 \mathrm{mg} . / \mathrm{ml}$. (SD $0.68 \mathrm{mg} . / \mathrm{ml}$.), and that IgA could be detected in cord sera in the months of April and May, which coincided with a period of heavy rainfall. The IgA concentration seemed too low to be detected by the method used in another group of cord sera taken in the dry season-September and October. The mean IgG value in maternal sera was higher than in the corresponding fetal sera done at the same time. Table I also shows that the mean $\operatorname{IgM}$ concentration in maternal sera is about six times higher than that in umbilical cord sera. One group of cord sera examined during the rainy season had a mean IgM value twice as high as that of the cord sera examined in the dry season.
The mean value for maternal caeruloplasmin was $0.96 \mathrm{mg} . / \mathrm{ml}$. (SD $0.50 \mathrm{mg} . / \mathrm{ml}$.) and for the corresponding cord sera it was $0.18 \mathrm{mg}$. $/ \mathrm{ml}$. (SD $0.10 \mathrm{mg} . / \mathrm{ml}$.). The significant difference here is obvious. The cord sera caeruloplasmin in September and October showed no significant difference from that in April and May. The maternal mean transferrin level was $2.40 \mathrm{mg}$. $/ \mathrm{ml}$. (SD 0.71 ) and the corresponding cord sera was $1.52 \mathrm{mg}$. $/ \mathrm{ml}$. (SD 0.16). The very high transferrin value of the cord blood in September and October can be clearly seen.

Fig. 1 and 2 show the scattergrams obtained when the various concentrations of maternal immunoglobulins and metal-containing proteins

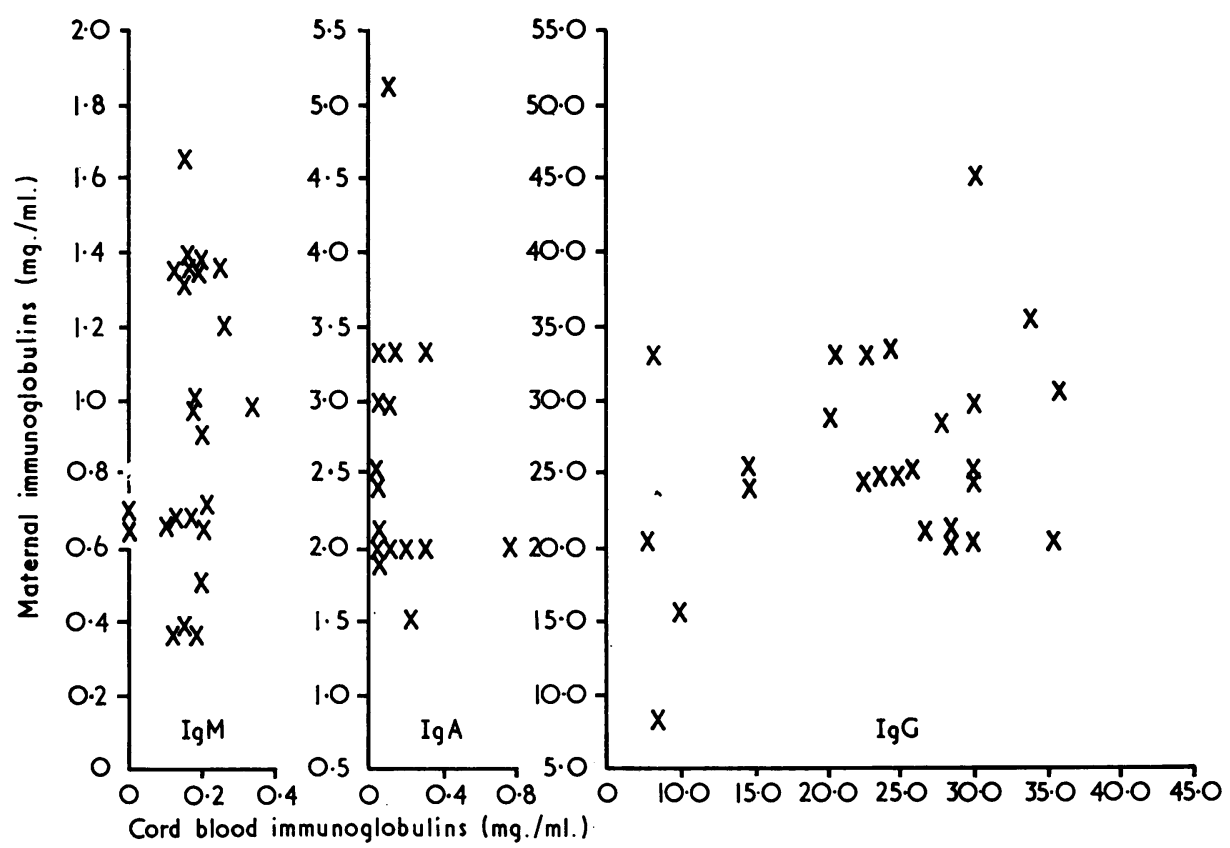

FIG. 1.-Concentration of maternal immunoglobulins plotted against concentration of cord blood immunoglobulins. 

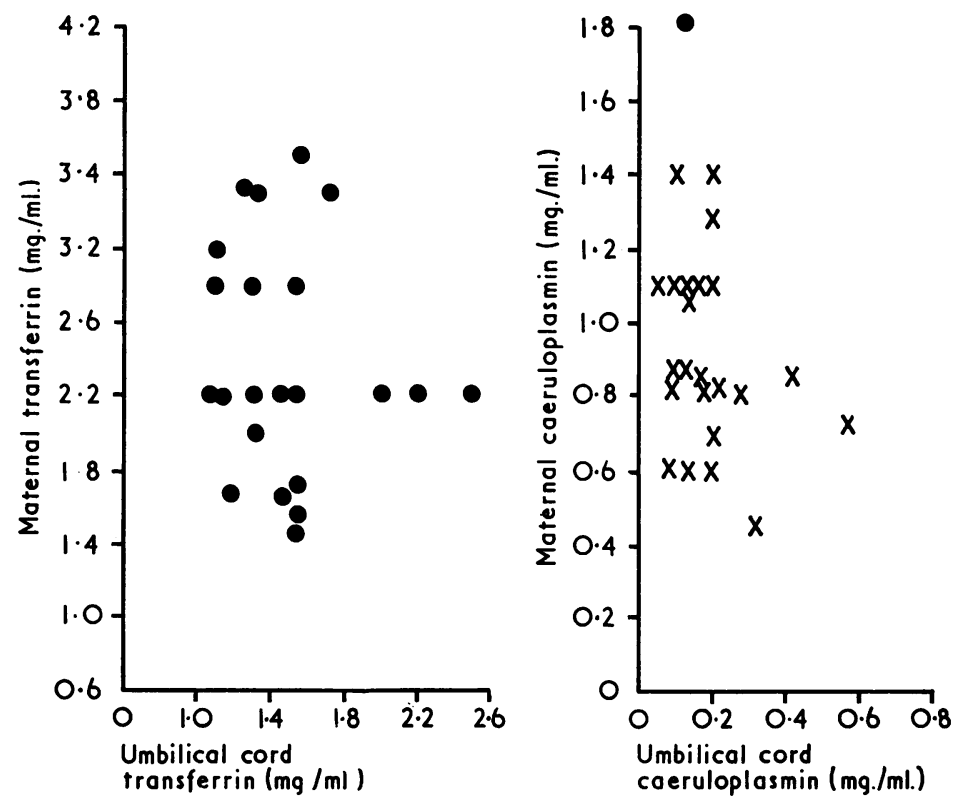

FIG. 2.-Concentration of maternal transferrin and caeruloplasmin plotted against umbilical cord blood transferrin and caeruloplasmin.

are plotted against the corresponding concentrations of cord blood immunoglobulins and metal-containing proteins. Fig. 1 shows that, of the immunoglobulins, there seems to be some correlation only between the maternal and fetal IgG (Rosen and Janeway, 1966; Michaux et al., 1966). That is, the concentration of fetal IgG tends to reflect the maternal IgG concentration. The regression coefficient for maternal-fetal IgG was calculated as $0 \cdot 270$. Paired maternal-fetal transferrin and caeruloplasmin concentrations do not seem related, though, as can be seen in Fig. 2, four maternal sera with relatively reduced caeruloplasmin were associated with fetal sera which had relatively increased caeruloplasmin values.
The results obtained with the mono-, di-, and trizygotic fetal blood are summarized in Table II. The similarity of the findings in the monozygotic fetal blood in comparison to those in the di- and trizygotic fetal blood is apparent.

\section{Discussion}

The results reported here show that when sensitive techniques are employed both $\operatorname{IgA}$ and $\operatorname{IgM}$ can be detected in cord sera, contrary to the widely-held opinion that only IgG is detected in cord sera (Humphrey and White, 1964). Edozien, Gilles, and Udeozo (1962) observed that after immunoelectrophoresis $\gamma$-globulin prepared from

TABLE II

Serum Immunoglobulins and Metal-containing Proteins (mg./ml.) in Mono-, Di-, and Trizygotic Fetal and Maternal Blood

\begin{tabular}{|c|c|c|c|c|c|c|c|c|c|}
\hline & & & & & $\operatorname{Ig} A$ & IgM & IgG & Caeruloplasmin & Transferrin \\
\hline $\begin{array}{l}\text { Maternal } \\
\text { Twin I } \\
\text { Twin II }\end{array}$ & $\begin{array}{l}\text { Male } \\
\text { Female }\end{array}$ & $\dot{\jmath}_{\text {dizygotic }}$ & $\begin{array}{l}\cdots \\
\cdots\end{array}$ & $\cdots$ & $\begin{array}{r}3 \cdot 30 \\
0 \cdot 29 \\
\mathrm{Nil}\end{array}$ & $\begin{array}{r}0.66 \\
0.20 \\
\text { Nil }\end{array}$ & $\begin{array}{r}33 \cdot 00 \\
8 \cdot 40 \\
23 \cdot 00\end{array}$ & $\begin{array}{l}0.62 \\
0.14 \\
0.09\end{array}$ & $\begin{array}{l}2 \cdot 80 \\
1 \cdot 12 \\
1 \cdot 32\end{array}$ \\
\hline $\begin{array}{l}\text { Maternal } \\
\text { Twin I } \\
\text { Twin II }\end{array}$ & $\left.\begin{array}{l}\text { Male } \\
\text { Male }\end{array}\right\}$ & $\begin{array}{l}\cdots \\
\text { nonozygotic }\end{array}$ & $\cdots$ & $\cdots$ & $\begin{array}{l}1 \cdot 35 \\
\mathrm{Nil} \\
\mathrm{Nil}\end{array}$ & $\begin{array}{l}0 \cdot 36 \\
0 \cdot 16 \\
0 \cdot 16\end{array}$ & $\begin{array}{l}28 \cdot 00 \\
28 \cdot 00 \\
20 \cdot 00\end{array}$ & $\begin{array}{l}0 \cdot 86 \\
0 \cdot 12 \\
0 \cdot 11\end{array}$ & $\begin{array}{l}2 \cdot 20 \\
1 \cdot 12 \\
1 \cdot 48\end{array}$ \\
\hline $\begin{array}{l}\text { Maternal } \\
\text { Triplet I } \\
\text { Triplet II } \\
\text { Triplet III }\end{array}$ & $\begin{array}{l}\text { Female } \\
\text { Male } \\
\text { Male }\end{array}$ & $\left\{\begin{array}{c}\cdots \\
\text { trizygotic }\end{array}\right.$ & $\cdots$ & $\cdots$ & $\begin{array}{c}2 \cdot 00 \\
\mathrm{Nil} \\
\mathrm{Nil} \\
0 \cdot 17\end{array}$ & $\begin{array}{l}1 \cdot 35 \\
0 \cdot 15 \\
0 \cdot 15 \\
0 \cdot 14\end{array}$ & $\begin{array}{l}24 \cdot 00 \\
24 \cdot 00 \\
14 \cdot 60 \\
23 \cdot 00\end{array}$ & $\begin{array}{l}1 \cdot 10 \\
1 \cdot 14 \\
0 \cdot 12 \\
0 \cdot 10\end{array}$ & $\begin{array}{l}1 \cdot 66 \\
1 \cdot 48 \\
1 \cdot 20 \\
1 \cdot 48\end{array}$ \\
\hline
\end{tabular}


pooled Nigerian cord sera contained traces of IgM. Franklin and Kunkel (1958) observed that the concentration of $\operatorname{IgM}$ in fetal blood was $1 / 10$ to $1 / 20$ that of maternal blood. West, Hong, and Holland (1962) detected IgM but no IgA in fetal blood. More recent evidence suggests that the human fetus can synthesize both IgM and IgA if adequately stimulated (Rosen and Janeway, 1966). It is not known whether there is any correlation between the level of these two immunoglobulins in the maternal circulation and their level in the corresponding fetal circulation. As far as we have been able to observe, there was no correlation between the concentration of IgA and IgM in cord blood and in maternal circulation. For instance, when the concentration of $\operatorname{IgA}$ or $\operatorname{IgM}$ was high in the maternal blood, one did not necessarily find a correspondingly high concentration of these immunoglobulins in umbilical cord blood. In fact, occasionally when the maternal IgM or IgA was high, only traces of, or no IgM or IgA, could be detected by the method used in the corresponding fetal blood. Conversely, relatively high IgM or IgA was occasionally detected in fetal blood when the corresponding maternal IgM or IgA was within the lower limits of normal. These results seemed to suggest that the $\operatorname{IgM}$ and $\operatorname{IgA}$ detected in cord blood were manufactured by the fetus itself and not transferred across the placenta, confirming the observations made by Hitzig (1961), van Furth, Schuit, and Hijmans (1965), and Rosen and Janeway (1966). In support of this was the observation that higher concentrations of $\operatorname{IgM}$ and $\operatorname{IgA}$ were detected in umbilical cord sera in the rainy season (AprilMay) than in the dry season (September-October). In addition, with the method used here, IgA was detected in only one of the dizygotic twins and one of the trizygotic triplets. The IgA concentration was too low to be detected in the other two trizygotic triplets and in the two monozygotic twins.

The higher IgM and IgA of cord sera in the wet seasons seem to result from increased antigenic stimuli either in the immediate fetal environment or in the maternal environment. For example, it is well known that malarial, helminth, and viral infections are increased during the wet season in Nigeria, and as Bruce-Chwatt (1965) has pointed out, malaria in pregnant African women frequently gives rise to heavy Plasmodium falciparum infection of the placenta. Fahey (1965) pointed out that rates of immunoglobulin synthesis were determined largely by response to environment.

It was interesting to note that the mean IgG value in the Nigerian fetal circulation tended to be lower than that found in the corresponding maternal circulation. Edozien (1961) has also reported that the electrophoretically measured $\gamma$-globulin was lower in Nigerian fetal blood than in maternal blood, and Michaux et al. (1966) observed that the IgG in Bantu fetal blood was significantly less than the Bantu maternal blood. This is indeed contrary to the findings reported for European maternal-fetal sera (Good, Condie, and Bridges, 1960; Derrington and Soothill, 1961; Edozien, 1961; Janeway, 1966; Michaux et al., 1966). The mean level for both maternal and fetal IgG in Nigerians is about twice that reported for European maternal-fetal blood in other parts of the world (Hitzig, 1961).

Although our results confirm the findings of other European workers, that $\mathrm{IgG}$ is selectively transported across the human placenta, they also suggest that other factors are operating here. The regression coefficient of 0.270 is significant, but shows that correlation between maternal-fetal IgG is far from being absolute. For example, the cord blood IgG in the dizygotic twins was $25 \%$ and $75 \%$ respectively of the corresponding maternal IgG concentration, and in the triplets one was $60 \%$ and two were $100 \%$ of the maternal concentration. The fetal sera of the monozygotic twins had identical IgG concentrations.

If selective transfer were the only factor responsible for IgG in umbilical cord blood one should expect to find similar concentrations in sets of twins or sets of triplets, regardless of whether they were mono-, di-, or trizygotic. This seems to suggest that the fetus can synthesize a certain proportion of its circulating IgG as well as the other immunoglobulins in amounts probably depending upon antigenic stimulation and development of the fetal immune system. Mean Nigerian maternal IgG level was of the same order as that in Nigerian male adults examined at the same time.

It should be emphasized that all 45 Nigerian umbilical cord sera examined had detectable caeruloplasmin, though other workers have reported that caeruloplasmin is physiologically absent from umbilical cord serum (Rosen and Janeway, 1966). The concentration of this metal-containing protein in maternal sera was five times higher than in fetal sera, but three times higher than in nornal adult males. On the other hand, the transferrin value in women at term is not significantly different from values found in healthy adult male Nigerians. Further studies on the development of the immunoglobulins and metal-containing proteins in Africans may help to explain such variables as the difference in response to chemotherapy between African and Caucasian children. 


\section{Summary}

Immunochemical quantitation of some proteins in paired Nigerian maternal-fetal blood showed that, in addition to $\operatorname{IgG}, \operatorname{IgA}$ and $\operatorname{IgM}$ can be detected in fetal circulation contrary to previous opinion. The concentration of IgG in the fetal circulation seemed to depend partly upon the presence of antigen in the fetal environment and particularly on the transfer of this immunoglobulin across the maternal placenta. IgG in the Nigerian fetus tended to be lower than in corresponding maternal sera, contrary to observations in Europeans. Lower values were found for the metal-containing proteins in umbilical cord sera than in maternal sera. The latter had about 3 times as much caeruloplasmin as did normal Nigerian male adults.

We would like to express our sincere thanks to Professor J. B. Lawson, Head of Department of Obstetrics and Gynaecology, for permission to obtain sera from his patients, to Mrs. P. O. Alalade, Superintendent, and the staff of the labour ward for their co-operation, and to Mr. Charles Umezude of the Hospital Medical Illustration Unit, for his help with the diagrams.

\section{REFERENCES}

Bruce-Chwatt, L. J. (1965). Malarial research for malaria eradication. Trans. roy. Soc. trop. Med. Hyg., 59, 105.

Charmot, G., and Andre, L. J. (1966). Les immuno-globulines. Med. trop., 26, 105.

Derrington, M. M., and Soothill, J. F. (1961). An immunochemical study of the proteins of amniotic fluid and of maternal and foetal serum. F. Obstet. Gynaec. Brit. Cwlth, 68, 755.

Edozien, J. C. (1961). The development of the serum protein pattern in Africans. F. clin. Path., 14, 644.
- Gilles, H. M., and Udeozo, I. O. K. (1962). Adult and cordblood gamma-globulin and immunity to malaria in Nigerians. Lancet, 2, 951.

—, and Udeozo, I. O. K. (1960). Serum copper, iron, and ironbinding capacity in kwashiorkor. $\mathcal{F}$. trop. Pediat., 6, 60.

Fahey, J. L. (1965). Antibodies and immunoglobulins. II. Normal development and changes in disease. $f$. Amer. med. Ass., 194, 255.

- , and McKelvey, E. M. (1965). Quantitative determination of serum immunoglobulins in antibody-agar plates. $\mathcal{f}$. Immunol., 94, 84.

Franklin, E. C., and Kunkel, H. G. (1958). Comparative levels of high molecular weights (19S) gamma globulin in maternal and umbilical cord sera. f. Lab. clin. Med., 52, 724.

van Furth, R., Schuit, H. R. E., and Hijmans, W. (1965). The immunological development of the human fetus. $\mathcal{f}$. exp. Med., 122, 1173.

Good, R. A., Condie, R. M., and Bridges, R. A. (1960). Development of the immune response in man and animals. Mechanism of Antibody In Formation. Proceedings of a Symposium, Prague, 1959, p. 118. Academy of Sciences, Prague.

Hitzig, W. H. (1961). Das Bluteiweissbild beim gesunden săugling. Helv. paediat. Acta, 16, 46.

Humphrey, J. H., and White, R. G. (1964). Immunology for Students of Medicine, 2nd ed. Blackwell, Oxford.

Janeway, C. A. (1966). The immunological system of the child. Part I: Development of immunity in the child. Arch. Dis. Childh., 41, 358.

Lamy, J. (1965). Dosage des Immunoglobulins seriques au cours de la trypanosomiase Africaine par Immunodiffusion simple. Thesis for the doctorate of the University of Dakar.

McFarlane, H. (1966). Immunoglobulins in Nigerians. Lancet, $2,445$.

- , and Voller, A. (1966). Studies on immunoglobulins of Nigerians. II. Immunoglobulins and malarial infection in Nigerians. F. trop. Med. Hyg., 69, 104.

Michaux, J. L., Heremans, J. F., and Hitzig, W. H. (1966). Immunoglobulin levels in cord-blood serum of Negroes and Caucasians. Trop. geogr. Med., 18, 10.

Rosen, F. S., and Janeway, C. A. (1966). The gamma globulins. 3. The antibody deficiency syndromes. New Engl. F. Med., 275, 709.

Turner, M. W., and Voller, A. (1966). Studies on immunoglobulins of Nigerians. I. The immunoglobulin levels of a Nigerian population. F. trop. Med Hyg., 69, 99.

West, C. D., Hong, R., and Holland, N. H. (1962). Immunoglobulin levels from the newborn period to adulthood and in immunoglobulin deficiency states. $\mathcal{F}$. clin. Invest., 42, 2054.

\section{Erratum}

Cushing's Syndrome Associated with an Islet-cell Tumour of the Pancreas in a Boy aged 2 years. By J. H. Burkinshaw, D. O'Brien, and J. E. H. Pendower. $(42,425$.

It is regretted that the date of the operation, October 8,1965 , was omitted from this paper. 